The detailed arrangements for the use of the telescope have yet to be worked out between the US National Aeronautics and Space Administration (NASA) and ESA.

ESA's decision has ruffled several British feathers. The Edinburgh proposal was based on the Starlink image processing system, which also uses the VAX computer and links six British universities. A confidential report by an ESA subcommittee, set up to evaluate the proposals, is said to have highlighted the scientific merits of the British scheme but put it in second place because the location was "far off from most member countries"'. Problems with pay differentials and apparent weaknesses in management and archiving were also mentioned, but these objections are dismissed by some British astronomers, who consider that a system based on Starlink would provide the best facility for European astronomers. Such a system could, however, be developed with advantage at ESO.

Philip Campbell

\section{Curien on top}

The council of the European Space Agency (ESA) has unanimously elected Professor Hubert Curien, president of the Centre National d'Etudes Spatiale, the French space agency, to be its next chairman. In a break with tradition, the council has also elected two vice-chairmen Dr Harry Atkinson, a British delegate to ESA, and Dr H. Grage, a Danish delegate. The hope is that the three new appointees, who represent separate national interests, will between them steer the agency onto a truly European course as it negotiates its future for the next ten years.

Despite the unanimous vote, however, Professor Curien's election was not without dissent, some delegates fearing that it might give too much weight to French arguments for the further development of the Ariane launcher. Britain had argued that it was time for a British chairman, the last one having been Sir Harrie Massey who chaired the European Space Research Organisation, ESA's predecessor, in the early 1970s. But other countries feared that the possible British candidates would be too partisan. An attempt by Italy and Switzerland to bring John Adams, ex-joint-director of CERN, the European centre for high-energy physics, into the competition failed on the grounds that he is not a delegate to the ESA council. John Adams had declined to apply for the post of ESA's directorgeneral when it became vacant last year.

In the event, the compromise has been to elect the British and Danish vice-chairmen to work with Professor Curien. With the current uncertainty over ESA's future programme, they are bound to play a more vital role than ESA chairmen in the recent past.

Judy Redfearn

\section{US space research}

\section{Halley again?}

\section{Washington}

A faint glimmer of hope that there may, after all, be a mission to Halley's comet filtered from the House of Representatives last week. The House has voted to include $\$ 5$ million in the budget to keep the project alive during 1982. But this is less than the $\$ 25$ million which scientists at Jet Propulsion Laboratory (JPL) of the National Aeronautics and Space Administration (NASA) say is necessary in the 1982 budget for the first stage of a $\$ 350$ million project.

The Republican-dominated Senate in passing a parallel bill last month did not include money for a Halley mission because it had not been requested by the Administration. Even if the proposed mission survives the compromise bill which the two legislative bodies must now negotiate, it still has to go through the appropriations process in which budgets rather than programmes are agreed.

Scientists at JPL are hoping to convince President Ronald Reagan that not mounting the mission would be a serious blow to national prestige, given that the European Space Agency (ESA), Japan and the Soviet Union (in partnership with Comecon countries and France) are preparing their own plans.

Dr Ray Heacock, JPL's choice as project manager for the Halley mission, said last week that the $\$ 5$ million would be sufficient to fund the project for the first three months of the next fiscal year. After that the President, if the mission is approved during negotiations on the 1983 budget for the agency, could direct NASA to reprogramme some of its 1982 funds.

The proposal has some strong supporters, particularly among those who feel that space science activities in NASA have been unfairly squeezed by the agency's preoccupation with the space shuttle.

The original plans have also been scaled down considerably. NASA had initially talked of a spacecraft which would travel alongside the comet on its way to a rendezvous with the smaller Tempel 2 comet. The latest plans are for a more modest mission using reserve equipment from previous planned missions to launch a spacecraft through the comet's tail within 600 to 1,000 kilometres of the nucleus.

There remains hope, however, that NASA may at least be able to resurrect its full participation in the International Solar Polar Mission, originally planned to fly two spacecraft in complementary orbits over the poles of the Sun. The agency's decision, at the prompting of the Office of Management and Budget, to eliminate funding for one of the spacecraft generated a storm of protest from European allies which are building the other.

The House authorization bill passed last week added $\$ 15$ million over the Admini- stration's request to allow NASA to continue construction of its spacecraft. This decision is likely to be supported in negotiations with Senate counterparts, where exastronaut Jack Schmitt is responsible for overseeing NASA programmes. The recommendations from the Appropriations Committee would also permit the project to continue, and given the importance which top State Department officials have attached to maintaining international commitments, it seems unlikely that the Senate Appropriations Committee, which meets to discuss NASA's budget next week, will object.

At the same time, NASA is unlikely to accept ESA's offer to build the second spacecraft, made during the negotiations to salvage the mission. Representative Don Fuqua, chairman of the House Science and Technology Committee, said that he was opposed to this proposal, because it was unfair to expose European contractors to the vagaries of US policy, and because even though the price-tag would be lower, spending the money in Europe would still result in a loss of US jobs and profits. TRW, the company selected by NASA as contractor for its own spacecraft, is now said to have found ways of reducing its costs considerably, a move likely to increase the mission's chances of survival.

David Dickson

\section{Trypanosomiasis}

\section{Question of breeding}

Schemes for breeding cattle resistant to trypanosomiasis are to be hatched at a research institute being planned in the Gambia (West Africa) with support from international aid agencies and foundations. The objective is to throw light on why N'Dama cattle in Africa appear to be genetically more resistant to infection by trypanosomes (also the infectious agent of African sleeping sickness) than are the more common Zebu cattle, and to find ways of propagating this resistance.

Much of the enthusiasm for the new institute comes from the President of the Gambia, Sir Dawda Kairaba Jawara, who was trained as a veterinary surgeon in Glasgow in the early 1950s, and who became leader of the People's Progressive Party in 1960. A preliminary meeting was held at Bellagio last year, and a meeting in the Gambia in May this year worked out a timetable on which further decisions must be made in time for a final decision about the project by January 1982.

Among international research projects, the Gambian research centre is unusual in that the African Development Bank seems to be prepared to take the lead in providing funds. Other interested parties include the European Community and the British government, the Food and Agriculture Organization and the World Health Organization of the United Nations, and research institutes in the World Bank 